\title{
A COMPARISON OF MAMMOGRAPHY AND ULTRASONOGRAPHY IN THE EVALUATION OF BREAST MASSES.
}

\author{
Sachin Prasad N*, Dana Houserkova
}

\author{
Department of Radiology*, Faculty of Medicine and Dentistry, Palacky University, Olomouc, Czech Republic \\ *e-mail:drsachinprasadn@yahoo.co.in
}

Received: October 10, 2007; Accepted: November 2, 2007

Keywords: Mammography/Ultrasonography/Breast masses/FNAC/Breast cancer

\begin{abstract}
Aim: Aim of the study is to evaluate breast masses using mammography (MG) and ultrasonography (USG) independently and in combination.

Materials and methods: Our study group consisted of 62 female patients, with breast symptoms such as palpable lumps, pain in the breast and nipple discharge who were examined prospectively over a period of 6 months.

All 62 patients were examined by both MG and USG independently. Fine needle aspiration cytology (FNAC) or core cut biopsy was done according to the findings of MG and USG and then the results were correlated with each modality finding.

Results: According to this study MG showed an efficiency of $81.8 \%$ compared to $95.5 \%$ for USG in detecting fibrocystic mastitis. However their combined approach resulted in $100 \%$. In the case of fibroadenomas, MG showed $75 \%$ efficiency and USG only $35 \%$ and the combination resulting in $93.7 \%$. For carcinomas, MG had an efficiency of $77.8 \%$ and USG $55.6 \%$, but the combination had an efficiency of $98.1 \%$. Overall, the histopathological results when correlated with each modality finding showed that MG had an efficiency of only $77.4 \%$ and USG only $69.8 \%$ when used alone in detecting these lesions of the breast compared to an efficiency of $98.1 \%$ obtained by their combined approach. In our study, we showed that there was no significant difference in sensitivity between MG and USG $(p=0.3768)$ but there was significant difference in MG alone and MG-USG combination $(p=0.0015)$ and USG alone and USG-MG combination $(\mathrm{p}=0.0001)$.

Conclusion: Our study confirmed that combined MG and USG had higher sensitivity rate than the sensitivity rate observed for either single modality. The diagnostic accuracy for carcinomas of the breast appear to improve when MG was combined with USG, even in cases which showed no evidence of microcalcification or other signs of abnormalities. Our study implies that, USG may be the only viable modality in pregnant and lactating women as it does not involve ionizing radiation and also in dense breast tissue, as density is a limiting factor for MG.
\end{abstract}

\section{INTRODUCTION}

Breasts are a secondary sexual characteristic in females. They are also the source of nutrition for the neonate and thus of mankind. They are also present in a rudimentary form in males. This tender, sensitive and delicate complex structure is constantly under the influence of hormones ${ }^{1,2}$.

The breast develops from mammary ridges. After menarche, the young virgin breast contains more dense connective tissue. With progression in age the dense breast becomes mixed glandular pattern tissue, and with further progression in age, breast begins to involute into fatty tissue.

Any aberration in this process leads to the susceptibility to a spectrum of localised pathologies like, hyperplastic and neoplastic changes. Of the various pathologies that afflict the breast, cancers are most often encountered and are the most dreaded ${ }^{1,2}$. Despite the gloomy prognosis, increased morbidity and reduced survival time, it can be controlled if detection and diagnosis are made in the earliest stages i.e., in the pre-invasive and clinically nonpalpable stage.

Detection of breast cancer in its earliest possible stage is the ultimate goal in imaging the breast, and the role of the radiologist is therefore vital. Radiology chiefly includes MG (mammography) and USG (ultrasonography) followed by biopsy. The incidence of breast cancer deaths can be reduced by $30 \%$ by the routine screening of healthy women with $\mathrm{MG}^{3,4}$. This is because breast changes like asymmetry, neodensity, distortion of fibroglandular architecture and microcalcifications are picked up earlier than lesions that become clinically palpable, or are sometimes detected by self-examination ${ }^{3,4}$.

USG plays a key role in differentiating cystic and solid masses. It is useful in the evaluation of palpable masses not visible in radiographically dense breasts, abscesses, masses that are not completely evaluable with $\mathrm{MG}$ and in young patients susceptible to radiation damage ${ }^{4,5}$.

Both MG and USG methods have been used in attempts to reduce the negative to positive biopsy ratio. Breast cancer mortality has declined since the early 1990s 
primarily due to increase in breast cancer awareness, screening and detection of early cancer ${ }^{6}$. The false-negative rate of mammography in the detection of breast cancer has been consistently reported to be approximately $10 \%$, as determined by studies such as the Breast Cancer Detection Demonstration Project ${ }^{6}$. These mammographically occult lesions are usually discovered by physical examination and often occur in women with mammographically dense breasts. Therefore, a negative mammographic result cannot exclude malignancy in women with a palpable mass; the lesion should be biopsied if clinically indicated. The sonographic evaluation of a palpable breast mass is based on three categories. First, if the lesion is a simple cyst, no further workup is required, although aspiration can be performed if desired by the patient or physician. Second, if the palpable lesion is a solid mass or complex cyst, further intervention is often required, such as fine-needle aspiration or core cut biopsy. Third, if findings from the sonography are negative (no discrete cystic or solid lesions are seen to correlate with the palpable mass) and the findings from the mammography are negative, then the treatment of the palpable abnormality is based on the results of the physical examination.

\section{MATERIALS AND METHODS}

A group of 62 female patients with breast symptoms, such as palpable lumps, pain in the breast and nipple discharge were examined prospectively over a period of 6 months. Both MG and USG were used independently to examine these patients.

\section{Clinical examination:}

In terms of age, 20 patients were less than $30 \mathrm{yrs}$, 19 patients between 31 to 40 yrs and the rest were above $40 \mathrm{yrs}$ as given in Table 1.

The patients were examined clinically and they showed either movable well-defined masses with a stony hard consistency, or restricted mobility of ill-defined masses with stony hard consistency. Some patients showed diffuse illdefined indurations with nipple discharge.

All the patients were given adequate explanation about the procedures and consent was obtained.

Table 1. Age distribution of the patients.

\begin{tabular}{|c|c|}
\hline Age group & No: of patients \\
\hline Below 30 years & 20 patients \\
\hline $31-40$ Years & 19 patients \\
\hline $41-50$ Years & 16 patients \\
\hline $51-60$ Years & 4 patients \\
\hline Above 60 years. & 3 patients \\
\hline
\end{tabular}

53 patients underwent FNAC (fine needle aspiration cytology) and core cut biopsy according to the findings of USG and MG. Later HPE (histopathological examination) results obtained was correlated with each modality finding. With the USG examination, cystic and solid masses were also analyzed. Using MG, the patients were analyzed for the parenchymal pattern of the breast according to TABAR'S classification and the histopathological examination (HPE) correlation of the masses present in them.

Masses in the breast were also classified according to the USG predominant pattern. These were cystic, solid and mixed patterns.

\section{Equipment:}

MG was performed in a stand type PHILIPS MAMMODIAGNOST which is a radiographic stand to radiograph the subject in a standing or sitting position in combination with mammographic x-ray tube assembly with compression paddle.

The cassette used for MG was KodakMin $30 \mathrm{R}$ with single sided screen with ultra sensitive films with emulsion coated on a single side of size 8 X10".

Each palpable lesion was evaluated with MG using the film-screen technique. Mediolateral oblique and craniocaudal images were obtained and assessed carefully.

USG was performed on a PHILIPS ENVISOR, real time scanner with a hand held linear electronic array transducer. The transducer could be operated in the frequency range of $7.5 \mathrm{MHz}$ and was provided with a built-in fluid offset. USG targeted to the palpable lesions were obtained for each patient by a professional breast imaging radiologist.

\section{RESULTS}

The HPE report revealed 9 patients with a carcinoma where, the MG detected 7 and USG alone detected only 5. There were 3 cases of cyst, which was clearly detected by USG, but the MG picked up only 2. Out of the 22 cases of fibrocystic mastitis, MG alone picked 18 whereas the USG missed only 1. Among 2 cases of infective pathology the MG missed 1, whereas the USG correctly spotted the 2. Of 16 cases of fibroadenoma, the MG detected 12 and the USG detected 5. And finally 1 case of cystosarcoma phylloids where both the modalities were successful, independently. This is shown clearly in Table 2.

As mentioned above, of 22 cases of fibrocystic mastitis, the MG alone picked up 18 cases, the remaining 4 were cases of sector mastitis which was misdiagnosed as diffuse lumps, and carcinoma could not be excluded. USG could not correctly diagnose 1 case out of the 22 , as the lesion appeared hypoechoic and showed no cysts or echogenic fibrous tissue. HPE in this case, revealed a glistening white lump, which was diagnosed as fibrosing mastopathy. By the combined USG and MG approach all 22 cases were correctly diagnosed. In this study USG provided a better description of the lesions in fibrocystic 


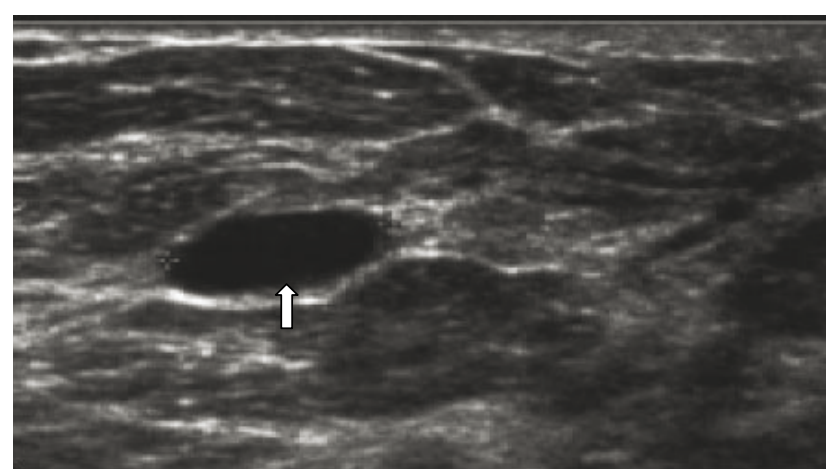

Fig. 1. Ultrasonography of a benign cyst.

The arrow points the cystic area in the breast.

mastitis. A tiny cyst surrounded by echogenic fibrous tissue was the typical appearance on USG. This could be easily distinguished from carcinoma, which appears hypoechoic. Hence, sector mastitis mistaken for carcinoma on MG, could be easily differentiated on USG.

Out of the 2 cases of infective pathologies, MG missed 1 case, which was misdiagnosed as carcinoma. This is because on MG breast abscess appears as a poorly defined mass or a mass with spiculated borders because of inadequate compression. USG alone could correctly pick 2 cases. The first case showed features of a simple cyst and was probably an infected cyst. The combined approach could do no better than USG alone. In our study, it was observed that most abscesses had no definite shape and had irregular contours with weak internal echoes in either homogeneous or scattered distribution. Most of the abscesses also had moving echoes within them due to floating debris, which was an important differentiating feature. Some of them showed posterior acoustic enhancement, while others did not. However, none of them showed posterior acoustic shadowing. It was therefore concluded that most of the abscesses that mimic carcinoma on MG could be correctly diagnosed by the combined approach. The above evidence shows that when the two modalities were combined, they yielded significant improvement in results than they did independently. The appearance of a benign

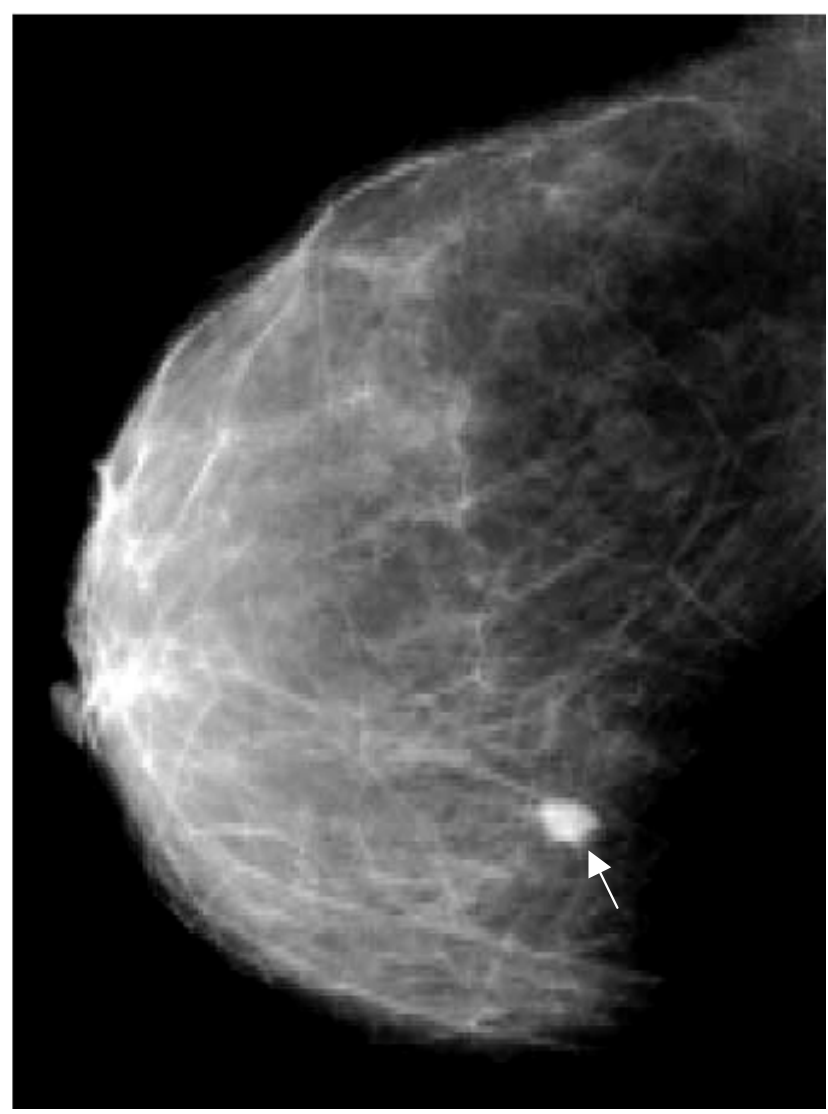

Fig. 2. Mammographic image of breast cancer The arrow points the area of cancer.

cyst under USG and image of breast cancer under MG are shown in figures $1 \& 2$ respectively. The analysis of solid and cystic masses by USG is given clearly in Table 3 and the mammographic parenchymal pattern of the breast according to Tabar's classification in Table 4.

According to MG, the lesions were also analyzed on the basis of their location (relation to their quadrant), number of asymmetrical lesions, well defined or merging with the adjacent normal breast tissue, according to the density of the lesion, margins, surrounding halo, and the

Table 2. HPE findings with comparative analysis.

\begin{tabular}{|l|c|c|c|c|}
\hline HPE diagnosis entities & No. Of Cases & $\begin{array}{c}\text { Mammography } \\
\text { Alone }\end{array}$ & USG Alone & Combined \\
\hline Fibrocystic mastitis & 22 & $18(82 \%)$ & $21(95 \%)$ & $22(100 \%)$ \\
\hline Infection & 2 & $1(50 \%)$ & $2(100 \%)$ & $2(100 \%)$ \\
\hline Fibroadenoma & 16 & $12(75 \%)$ & $5(31 \%)$ & $15(93 \%)$ \\
\hline Cyst & 3 & $2(67 \%)$ & $3(100 \%)$ & $3(100 \%)$ \\
\hline Carcinoma & 9 & $7(77 \%)$ & $5(55 \%)$ & $9(100 \%)$ \\
\hline Phylloids tumour & 1 & $1(100 \%)$ & $1(100 \%)$ & $1(100 \%)$ \\
\hline Total & 53 & $41(77 \%)$ & $37(70 \%)$ & $52(98 \%)$ \\
\hline
\end{tabular}


Table 3. Ultrasonographic Findings.

\begin{tabular}{|c|c|c|c|c|c|}
\hline S.NO & 1 & 2 & 3 & 4 & 5 \\
\hline HPE & Fibrocystic Mastitis & Fibro adenoma & Cyst & Infection & Malignancy \\
\hline $\begin{array}{l}\text { No: of Cases } \\
\text { Diagnosed }\end{array}$ & (1) & 5 & 3 & 2 & 5 \\
\hline Quadrants & Upper outer & $\begin{array}{l}\text { Upper outer } \\
\text { Retro-areolar }\end{array}$ & $\begin{array}{c}\text { Upper outer } \\
\text { any }\end{array}$ & Upper outer & $\begin{array}{c}\text { Upper outer, lower } \\
\text { outer, any }\end{array}$ \\
\hline $\begin{array}{l}\text { Unilateral (or) } \\
\text { Bilateral }\end{array}$ & Bilateral & Both & Unilateral & Unilateral & Unilateral \\
\hline $\begin{array}{l}\text { Echogenicity of } \\
\text { lesion }\end{array}$ & Hypoechoic & Hypoechoic & Anechoic & $\begin{array}{l}\text { Anechoic to } \\
\text { hypoechoic }\end{array}$ & Mixed echogenicity \\
\hline Margin & Diffuse & Well defined & Well defined & Well defined & Irregular \\
\hline $\mathrm{Ca}++$ & - & Coarse & - & - & $\begin{array}{l}7 \text { cases } \\
\text { Show micro- } \\
\text { calcification }\end{array}$ \\
\hline Single (or) Multiple & Single & & Single & Single & Single \\
\hline Skin Infiltration & - & - & - & Focal thickening & $\begin{array}{c}3 \text { cases } \\
\text { Skin thickening }\end{array}$ \\
\hline With Internal echoes & - & $\begin{array}{l}\text { Homogenously } \\
\text { filling up when gain } \\
\text { is raised. }\end{array}$ & $\begin{array}{c}\text { Central Area } \\
\text { persistently } \\
\text { Anechoic }\end{array}$ & $\begin{array}{l}\text { With internal echoes } \\
\text { (moving) }\end{array}$ & 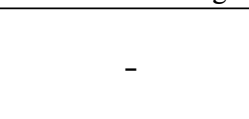 \\
\hline $\begin{array}{l}\text { Without Internal } \\
\text { echoes }\end{array}$ & + & 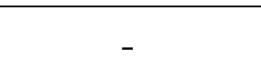 & $\begin{array}{c}++ \\
(2 \text { Cases })\end{array}$ & - & - \\
\hline $\begin{array}{l}\text { Posterior } \\
\text { Enhancement }\end{array}$ & - & 2 Cases & $\begin{array}{c}++ \\
(2 \text { Cases })\end{array}$ & ++ & 3 Cases \\
\hline $\begin{array}{l}\text { Posterior Acoustic } \\
\text { shadowing }\end{array}$ & - & 3 Cases & - & - & 18 Cases \\
\hline
\end{tabular}

Table 4. Mammographic parenchymal pattern according to TABAR'S classification.

\begin{tabular}{|l|c|c|c|c|}
\hline Consistency of the breast under TABAR & Normal & Benign & Malignant & Total \\
\hline Mixed glandular pattern/TABAR I & 2 & 4 & 5 & 11 \\
\hline Fatty Breast/TABAR II \& III & 1 & 12 & 1 & 14 \\
\hline Dense Breast/TABAR IV \& V & 18 & 18 & 7 & 37 \\
\hline Total & 21 & 34 & 62 \\
\hline
\end{tabular}

presence or absence of intra mammary and axillary lesions. The analysis is given in Table 5.

Various limitations of mammography were that, solid cystic masses could not be differentiated and intra cystic lesions could not be diagnosed. The young breast had dense fibroglandular parenchyma, which obscured masses under MG. Overlapping structures limited complete visualisation of masses. The major advantages of MG were that, microcalcifications could be seen well and multicentric carcinomas could be diagnosed. The limitations of USG were that, isoechoeic masses were at times missed if they were especially small. Microcalcifications if small were also not picked and lesions within large fatty breasts were difficult to diagnose. However, the real advantage of USG was that solid and cystic masses could be differentiated well and young breasts with dense fibro-glandular parenchyma could be imaged with ease. Intracystic lesions were easily picked up, contour of the masses were excel- lently visualized in spite of associated fibrocystic mastitis and tender breasts could be examined painlessly.

Various limitations and advantages of MG and USG are given clearly in Table 6 and 7 respectively.

According to this study, MG had a sensitivity of $81.8 \%$ compared to $95.5 \%$ for USG for detecting fibrocystic mastitis, but their combined approach resulted in $100 \%$. Apropos fibroadenomas, MG showed $75 \%$ sensitivity and USG $35 \%$ and the combination $93.7 \%$. For carcinomas, MG had a sensitivity of $77.8 \%$ and USG $55.6 \%$, but the combination had a sensitivity of $98.1 \%$. Overall, the histopathological results when correlated with each modality findings, revealed that MG had a sensitivity of $77.4 \%$ and USG $69.8 \%$ when used alone in detecting these lesions of the breast compared to a sensitivity of $98.1 \%$ obtained by their combined approach. This is shown in Table 8.

This study showed that there was no significant difference in sensitivity between MG and USG $(p=0.3768)$ 
Table 5. Mammographic Findings.

\begin{tabular}{|c|c|c|c|c|c|}
\hline S.NO & 1 & 2 & 3 & 4 & 5 \\
\hline HPE & Fibrocystic Mastitis & Fibroadenoma & Cyst & Infection & Malignancy \\
\hline $\begin{array}{l}\text { No: of } \\
\text { Cases } \\
\text { Diagnosed }\end{array}$ & 18 & 12 & 2 & 1 & 7 \\
\hline Quadrants & Upper outer & $\begin{array}{l}\text { Upper outer Retro- } \\
\text { areolar }\end{array}$ & Upper outer any & Upper outer & $\begin{array}{c}\text { Upper outer, lower } \\
\text { outer, any }\end{array}$ \\
\hline $\begin{array}{l}\text { Unilateral (or) } \\
\text { Bilateral }\end{array}$ & Bilateral & Both & Unilateral & Unilateral & Unilateral \\
\hline Density of the lesion & Increased & $\begin{array}{l}\text { Increased Round, } \\
\text { Oval \& Lobulated }\end{array}$ & $\begin{array}{l}\text { Increased and } \\
\text { round }\end{array}$ & Increased density & $\begin{array}{c}\text { Asymmetry, } \\
\text { Increased density }\end{array}$ \\
\hline Margin & Diffuse & Well defined & Well defined & Well defined & Irregular \\
\hline $\mathrm{Ca}++$ & - & Coarse & - & - & Micro-calcification \\
\hline $\begin{array}{l}\text { Single } \\
\text { Or Multiple }\end{array}$ & - & Both & Single & Single & $\begin{array}{l}\text { Single one } \\
\text { case showed } \\
\text { multicentric }\end{array}$ \\
\hline $\begin{array}{l}\text { Surrounding } \\
\text { Halo }\end{array}$ & - & ++ & - & - & - \\
\hline Remaining breast pattern & - & Mixed glandular & $\begin{array}{l}\text { Fibro glandular } \\
\text { Mixed Pattern }\end{array}$ & Mixed Pattern & $\begin{array}{c}\text { Mixed Pattern } \\
\text { Fatty }\end{array}$ \\
\hline Skin thickening & - & - & - & Present & Present \\
\hline $\begin{array}{l}\text { Fibro-glandular } \\
\text { architectures }\end{array}$ & Diffuse dense. & $\begin{array}{l}\text { Surrounding } \\
\text { architecture not } \\
\text { distorted }\end{array}$ & $\begin{array}{l}\text { Surrounding } \\
\text { architecture not } \\
\text { distorted }\end{array}$ & $\begin{array}{l}\text { Surrounding } \\
\text { Architecture not } \\
\text { distorted }\end{array}$ & Distorted \\
\hline
\end{tabular}

Table 6. Various limitations of mammography (MG) and ultrasolongraphy (USG).

\begin{tabular}{|l|l|}
\hline \multicolumn{1}{|c|}{ Mammography } & \multicolumn{1}{|c|}{ Ultrasonography } \\
\hline Solid and cystic masses cannot be differentiated & Operator Dependent \\
\hline Intracystic lesions cannot be diagnosed & Isoechoic masses may be missed especially when small \\
\hline $\begin{array}{l}\text { Young breasts have dense Fibroglandular parenchyma } \\
\text { and Obscure masses. }\end{array}$ & Micro-calcification may not be picked up \\
\cline { 1 - 2 } $\begin{array}{l}\text { Fibrocystic mastitis may mask the margins of a lump } \\
\text { benign lump appears malignant. }\end{array}$ & $\begin{array}{l}\text { Circumscribed carcinoma may be labelled as benign } \\
\text { masses. }\end{array}$ \\
\cline { 1 - 2 } Sector mastitis mimics lumps & $\begin{array}{l}\text { Lesions within large fatty breasts are difficult } \\
\text { to diagnose }\end{array}$ \\
\cline { 1 - 2 } $\begin{array}{l}\text { Overlapping structures may limit complete visualization } \\
\text { of a mass. }\end{array}$ & Multi-centric carcinoma may be missed. \\
\cline { 1 - 2 } Abscess and tuberculosis may mimic carcinoma. & \multicolumn{1}{|c|}{} \\
\cline { 1 - 2 } $\begin{array}{l}\text { Evaluation of Tender breast is difficult and often inad- } \\
\text { equate. }\end{array}$ & \\
\cline { 1 - 2 } $\begin{array}{l}\text { Lactating or pregnant patients cannot be adequately } \\
\text { evaluated. }\end{array}$ & \\
\cline { 1 - 2 } &
\end{tabular}


Table 7. Given below are the advantages of mammography and ultrasolongraphy.

\begin{tabular}{|c|c|}
\hline Mammography & Ultrasonography \\
\hline 1. Micro calcifications can be seen well. & 1. Solid and cystic mass can be differentiated. \\
\hline 2. Multicentric carcinoma can be diagnosed. & 2. Intracystic lesions can be easily picked up. \\
\hline $\begin{array}{l}\text { 3. Characteristics of the mass like margins and loca- } \\
\text { tions are better defined. }\end{array}$ & $\begin{array}{l}\text { 3. Young breasts with dense fibro glandular } \\
\text { parenchyma can be imaged with ease. }\end{array}$ \\
\hline & $\begin{array}{l}\text { 4. Contour of masses excellently visualized in spite } \\
\text { of associated fibrocystic mastitis. }\end{array}$ \\
\hline & $\begin{array}{l}\text { 5. All cases of mastitis mimicking a lump can be } \\
\text { easily distinguished. }\end{array}$ \\
\hline & 6. Tender breasts can be examined painlessly. \\
\hline & $\begin{array}{l}\text { 7. Most abscesses showing-floating debris and can } \\
\text { easily be diagnosed. }\end{array}$ \\
\hline & 8. Pregnant patients can be examined safely. \\
\hline
\end{tabular}

Table 8. Sensitivity of mammography (MG) alone, ultrasonography

(USG) alone and mammography-ultrasonography combined.

\begin{tabular}{|c|c|c|c|c|}
\hline & & \multicolumn{3}{|c|}{ Sensitivity (95\% Confidence Interval) } \\
\hline & No & Mammography & USG & Mammography + USG \\
\hline Infection & 2 & & & \\
\hline Cyst & 3 & & & \\
\hline $\begin{array}{l}\text { Phylloids } \\
\text { tumour }\end{array}$ & 1 & & & \\
\hline $\begin{array}{l}\text { Fibrocystic } \\
\text { mastitis }\end{array}$ & 22 & $\begin{array}{c}(18 / 22), 81.8 \% \\
(59.7-94.8)\end{array}$ & $\begin{array}{c}(21 / 22), 95.5 \% \\
(77.2-99.9)\end{array}$ & $\begin{array}{c}(22 / 22), 100 \% \\
(84.6-100)\end{array}$ \\
\hline Fibroadenoma & 16 & $\begin{array}{c}(12 / 16), 75.0 \% \\
(47.6-92.7)\end{array}$ & $\begin{array}{c}(5 / 16), 31.2 \% \\
(11.0-58.6)\end{array}$ & $\begin{array}{c}(15 / 16), 93.7 \% \\
(69.8-99.8)\end{array}$ \\
\hline Carcinoma & 9 & $\begin{array}{c}(7 / 9), 77.8 \% \\
(40.0-97.2)\end{array}$ & $\begin{array}{c}(5 / 9), 55.6 \% \\
(21.2-86.3)\end{array}$ & $\begin{array}{c}(9 / 9), 100 \% \\
(66.4-100)\end{array}$ \\
\hline Total & 53 & $\begin{array}{c}(41 / 53), 77.4 \% \\
(64.4-93.6)\end{array}$ & $\begin{array}{c}(37 / 53), 69.8 \% \\
(55.6-87.1)\end{array}$ & $\begin{array}{c}(52 / 53), 98.1 \% \\
(93.9-100)\end{array}$ \\
\hline
\end{tabular}

Table 9. The difference in p-value between MG and USG, MG alone and MG+USG combined, USG alone and $\mathrm{MG}+\mathrm{USG}$ combined.

\begin{tabular}{|l|c|c|c|}
\hline & MG-USG & $\begin{array}{c}\text { MG alone - } \\
\text { (MG + USG combined) }\end{array}$ & $\begin{array}{c}\text { USG alone - } \\
\text { (MG + USGcombined) }\end{array}$ \\
\hline Fibrocystic mastitis & 0.159 & 0.043 & 0.32 \\
\hline Fibroadenoma & 0.0189 & 0.155 & 0.0009 \\
\hline Carcinoma & 0.328 & 0.1553 & 0.0386 \\
\hline Total & 0.3768 & 0.0015 & 0.0001 \\
\hline
\end{tabular}


but there was a significant difference in $\mathrm{MG}$ alone and MG-USG combination ( $p=0.0015$ ) and USG alone and USG-MG combination ( $p=0.0001)$. This is shown clearly in Table 9.

\section{DISCUSSION}

Breast cancer is one of the most prevalent cancers in the world among women. Breast masses are common and usually benign, but effective evaluation and prompt diagnosis can rule out malignancy.

Masses within the breast (whether symptomatic or asymptomatic) are frequently diagnosed by mammography. It is essential to define exactly what constitutes the lesion mass in order to differentiate benign from malignant lesions. Mammography, the primary method of detection and diagnosis of breast disease has a proven sensitivity of $85 \%-95 \%{ }^{7}$. However, additional diagnostic procedures often become necessary in view of its low specificity. Younger women have denser breasts, the use of oestrogen replacement therapy increases breast density and oestrogen replacement therapy use is most common during and shortly after the begining of menopause and declines thereafter. In addition, dense breast parenchyma and younger age group are associated with lower mammographic sensitivity in some but not all women. Presently non-invasive imaging methods like magnetic resonance imaging (MRI), thermography and colour doppler ultrasound (USG) are being used as adjunctive procedures ${ }^{7}$. Though a definitive diagnosis is possible with non-invasive imaging procedures, for most lesions biopsy/ fine needle aspiration cytology are essential for obtaining reliable results ${ }^{7-9}$. In the majority of cases surgical biopsy detects the lesion as benign and has served only to provide diagnosis, since surgical removal of these lesions are unnecessary unless the clinical signs and symptoms warrant for it. Breast cancers are associated with tumour angiogenesis. Increase in the number of blood vessels, increased vascular permeability, increased tumour blood volume, arteriovenous shunt formation, altered capillary bed transmit time, increased interstitial pressure due to absent lymphatic vessels in tumours result form tumour angiogenesis and create characteristic, identifiable patterns including the distribution pattern of intravenously injected contrast medium that can be distinguished from those associated with benign lesions. This positive rim sign could also be delineated by colour doppler ultrasound system. Vessel density in fibroademonas is more uniform throughout the tumour than it is in carcinomas, with no statistically significant difference between periphery and centre. Rim enhancing carcinomas were observed to have varying degrees of central desmoplasia, associated with lower vessel density. Rim enhancement was observed in 5 of 16 carcinomas, but none of the rim enhancing carcinomas exhibited central necrosis ${ }^{7}$

Patients with palpable breast masses commonly present for imaging evaluation. Unfortunately, false-negative mammographic findings in the setting of a palpable breast mass have been estimated at between $4 \%$ and $12 \%{ }^{10,11}$. Therefore, malignancy cannot be excluded when mammographic findings of a palpable mass are negative. Treatment of a palpable mass in this setting is based on the results of physical examination, with aspiration or biopsy performed on clinically suspicious lesions. Sonography is used as an adjunct to mammography to further evaluate palpable masses, especially in women with mammographically dense breasts. Sonography often detects cysts or solid lesions that are obscured on the mammogram by the surrounding fibroglandular tissue and can reduce the number of surgical biopsies required when cysts are identified ${ }^{10,11}$. Although the role of sonography initially was to establish or exclude the cystic nature of a mass, it has expanded with improvements in equipment. Sonographic findings can often confirm a cancer that is obscured mammographically by dense breast tissue. Sonographic technology for breast imaging has dramatically improved in the last decade. With further improvements in sonographic technology and careful prospective real-time evaluation of palpable breast lumps, perhaps the negative predictive value will one day approach $100 \%$, ideally providing complete confidence for follow-up rather than recommending biopsy of these lesions.

MG can help physicians determine whether a lesion is potentially malignant and also screen for occult disease in the surrounding tissue ${ }^{12-14}$. Radio-opaque ball bearings marks the location of the mass and spot compression and magnification views can clarify the breast mass and determine its density ${ }^{15}, 16$. If old films are available, they are compared with the new images. MG is up to 87 percent accurate in detecting cancer ${ }^{17-22}$. Its specificity is 88 percent, and its positive predictive value may be as high as 22 percent $^{22}$. USG can effectively distinguish solid masses from cysts, which account for approximately 25 percent of breast lesions ${ }^{18,19}$. When strict criteria for cyst diagnosis are met, USG has a sensitivity of 89 percent and a specificity of 78 percent in detecting abnormalities in symptomatic women. ${ }^{18}$ Recurrent or complex cysts may signal malignancy; therefore, further evaluation of these lesions is required ${ }^{19}$.

Although USG is not considered a screening test, it is more sensitive than MG in detecting lesions in women with dense breast tissue ${ }^{18,20}$. It is useful in discriminating between benign and malignant solid masses, ${ }^{18,21}$ and it is superior to $\mathrm{MG}$ in diagnosing clinically benign palpable masses (i.e., up to 97 percent accuracy versus 87 percent for MG). ${ }^{21}$ It was found from the literatures that MG is a well-established diagnostic modality for the breast. It has high diagnostic yield, but is not $100 \%$ accurate ${ }^{24,25}$. MG when combined with USG can yield significant improvement in accuracy rates.

\section{CONCLUSION}

This study confirms that MG and USG when combined has higher sensitivity than the sensitivity observed for a single modality. The diagnostic accuracy of carcino- 
mas of the breast appear to improve when MG was combined with USG, even in cases which showed no evidence of microcalcification or other signs of abnormalities.

The study also implies that, USG may be the only modality employed in lactating and pregnant patients as it does not involve ionizing radiation and it may also be used when the density of the breast tissue precludes MG. Similarly, tender breasts with suspected inflammation are examined with USG, owing to the pain caused by compression.

Thus a combined MG and USG approach to detect breast diseases is significantly more helpful in accurate evaluation of breast pathologies than when either modality is used alone.

\section{BIBLIOGRAPHY}

1. Clarke D, Sudhakaran N, Gateley CA. Replace fine needle aspiration cytology with automated core biopsy in the triple assessment of breast cancer. Ann R Coll Surg Engl 2001; 83:110-2.

2. Schoonjans JM, Brem RF. Fourteen-gauge ultrasonographically guided large-core needle biopsy of breast masses. J Ultrasound Med 2001; 20:967-72

3. Morris KT, Vetto JT, Petty JK, Lum SS, Schmidt WA, Toth-Fejel $\mathrm{S}$, et al. A new score for the evaluation of palpable breast masses in women under age 40. Am J Surg 2002; 184:346-7.

4. Wendie A. Berg, MD, PhD, Lorena Gutierrez, MD, Moriel S. NessAiver, PhD, W. Bradford Carter, MD2, Mythreyi Bhargavan, PhD, Rebecca S. Lewis, MPH and Olga B. Ioffe, MD Diagnostic Accuracy of mammography, Clinical Examination, US, and MR Imaging in Preoperative Assessment of Breast Cancer 1 radiology. rsnajnls.org/cgi/content/abstract/233/3/830

5. Kerlikowske K, Smith-Bindman R, Ljung BM, Grady D. Ann Intern Med. 2003 Aug 19; 139(4): 274-84. Evaluation of abnormal mammography results and palpable breast abnormalities. Ann Intern Med. 2003 Aug 19; 139(4): 274-84.

6. Kopans DB. Breast imaging. Philadelphia: Lippincott, 1998:29 $-54$

7. Chakraborti KL, Bahl P, Sahoo M, Ganguly SK, Oberoi C. Magentic resonance imaging of breast masses: Comparison with mammography. Indian J Radiol Imaging 2005; 15:381-387

8. Pande AR, Lohani B, Sayami P, Pradhan S.Predictive value of ultrasonography in the diagnosis of palpable breast lump. Kathmandu Univ Med J (KUMJ). 2003 Apr-Jun; 1(2): 78-84.

9. Fajardo LL. Screening mammography, sonography of dense fibrocystic breast tissue. AJR Am J Roentgenol. 2003 Dec; 181(6): 1715 .

10. Dennis MA, Parker SH, Klaus AJ, Stavros AT, Kaske TI, Clark SB Breast biopsy avoidance: the value of normal mammograms and normal sonograms in the setting of a palpable lump. Radiology 2001; 219:186 -191

11. Weinstein SP, Conant EF, Orel SG, Zuckerman JA, Czerniecki B, Lawton TJ. Retrospective review of palpable breast lesions after negative mammography and sonography. J Women's Imaging 2000; $2: 15-18$

12. Kerlikowske K, Smith-Bindman R, Ljung BM, Grady D. Evaluation of abnormal mammography results and palpable breast abnormalities. Ann Intern Med 2003; 139:274-84.

13. Shetty MK, Shah YP, Sharman RS. Prospective evaluation of the value of combined mammographic and sonographic assessment in patients with palpable abnormalities of the breast. J Ultrasound Med 2003; 22:263-8.

14. Kumle M, Weiderpass E, Braaten T, Persson I, Adami HO, Lund E. Use of oral contraceptives and breast cancer risk: the NorwegianSwedish Women's Lifestyle and Health Cohort Study. Cancer Epidemiol Biomarkers Prev 2002; 11:1375-81.

15. Budai B, Szamel I, Sulyok Z, Nemet M, Bak M, Otto S, et al. Characteristics of cystic breast disease with special regard to breast cancer development. Anticancer Res 2001; 21:749-52.

16. Barton MB, Harris R, Fletcher SW. The rational clinical examination. Does this patient have breast cancer? The screening clinical breast examination: should it be done? How? JAMA 1999; 282:1270-80.

17. Osuch JR, Reeves MJ, Pathak DR, Kinchelow T. BREASTAID: clinical results from early development of a clinical decision rule for palpable solid breast masses. Ann Surg 2003; 238:728-37.

18. Moss HA, Britton PD, Flower CD, Freeman AH, Lomas DJ Warren RM. How reliable is modern breast imaging in differentiating benign from malignant breast lesions in the symptomatic population? Clin Radiol 1999; 54:676-82.

19. Berg WA, Campassi CI, Ioffe OB. Cystic lesions of the breast: sonographic-pathologic correlation. Radiology 2003; 227:183-91.

20. Kolb TM, Lichy J, Newhouse JH. Comparison of the performance of screening mammography, physical examination, and breast US and evaluation of factors that influence them: an analysis of 27,825 patient evaluations. Radiology 2002; 225:165-75.

21. Lister D, Evans AJ, Burrell HC, Blamey RW, Wilson AR, Pinder $\mathrm{SE}$, et al. The accuracy of breast ultrasound in the evaluation of clinically benign discrete, symptomatic breast lumps. Clin Radiol 1998; 53:490-2.

22. Barlow WE, Lehman CD, Zheng Y, Ballard-Barbash R, Yankaskas BC, Cutter GR, et al. Performance of diagnostic mammography for women with signs or symptoms of breast cancer. J Natl Cancer Inst 2002; 94:1151-9.

23. Leichter I, Buchbinder S, Bamberger P, Novak B, Fields S, Lederman R. Quantitative characterization of mass lesions on digitized mammograms for computer-assisted diagnosis. Invest Radiol 2000; 35:366-72.

24. Obenauer S, Luftner-Nagel S, von Heyden D, Munzel U, Baum F, Grabbe E. Screen film vs full-field digital mammography: image quality, detectability and characterization of lesions [published correction appears in Eur Radiol 2002; 12:2388]. Eur Radiol 2002; 12:1697-702.

25. Lewin JM, Hendrick RE, D'Orsi CJ, Isaacs PK, Moss LJ, Karellas A, et al. Comparison of full-field digital mammography with screenfilm mammography for cancer detection: results of 4,945 paired examinations. Radiology 2001; 218:873-80.

26. Westenend PJ, Sever AR, Beekman-De Volder HJ, Liem SJ. A comparison of aspiration cytology and core needle biopsy in the evaluation of breast lesions. Cancer 2001; 93:146-50. 